\title{
Systematic Literature Review: Current Products, Topic, and Implementation of Graph Database
}

\author{
Adhy Rizaldy ${ }^{1}$, Sirli Fahriah ${ }^{2}$, Nahrun Hartono ${ }^{3}$ \\ ${ }^{\mathbf{1}, \mathbf{3}}$ Lecturer of Information System Department, Faculty of Sains dan Teknologi, Universitas Islam Negeri Alauddin Makassar \\ ${ }^{2}$ Lecturer of Informatics Engineering Department, Faculty of Teknik Elektro, Politeknik Negeri Semarang
}

\begin{tabular}{l} 
ARTICLE INFO \\
\hline Article history: \\
Received December 28, 2020 \\
Revised April 10, 2021 \\
Accepted 15 April 2021 \\
\hline Keywords: \\
Graph database; \\
Neo4j; \\
Graph model; \\
NoSQL
\end{tabular}

\begin{abstract}
Planning, developing, and updating software cannot be separated from the role of the database. From various types of databases, graph databases are considered to have various advantages over their predecessor, relational databases. Graph databases then become the latest trend in the software and data science industry, apart from the development of graph theory itself. The proliferation of research on GDB in the last decade raises questions about what topics are associated with GDB, what industries use GDB in its data processing, what the GDB models are, and what types of GDB have been used most frequently by users in the last few years. This article aims to answer these questions through a Literature Review, which is carried out by determining objectives, determining the limits of review coverage, determining inclusion and exclusion criteria for data retrieval, data extraction, and quality assessment. Based on a review of 60 studies, several research topics related to GDB are Semantic Web, Big Data, and Parallel computing. A total of $19(30 \%)$ studies used Neo4j as their database. Apart from Social Networks, the industries that implement GDB the most are the Transportation sector, Scientific Article Networks, and general sectors such as Enterprise Data, Biological data, and History data. This Literature Review concludes that research on the topic of the Graph Database is still developing in the future. This is shown by the breadth of application and the variety of new derivatives of GDB products offered by researchers to address existing problems.
\end{abstract}

This work is licensed under a Creative Commons Attribution-Share Alike 4.0

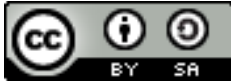

\section{Adhy Rizaldy}

Information System Department, Faculty of Sains dan Teknologi, Kampus II Universitas Islam Negeri Alauddin Jln. Sultan Alauddin No. 63, Samata-Gowa

Email: adhy.rizaldy@uin-alauddin.ac.id

\section{INTRODUCTION}

The database is a computerized data file set [1], where the data is interconnected and organized; hence the information can be obtained easily. With the database in a different tier, software or system has a lighter workload, thus more precise data processing and information obtained instantaneously (without intermission).

The increasingly massive growth of digital data has encouraged the creation of various types of new databases, including graph databases. A graph database is a database model that consists of nodes, edges, and relationships [2]. Based on graph theory, a Graph Database is suitable for use on data sets where the chain between nodes is very important. In addition, GDB performance tends to be stable even as the data set increases, as queries can be localized to Graphs. Referring to these advantages, various platforms and social media such as Facebook, LinkedIn, and Adobe cloud have used the Graph Database to handle a huge amount of data and queries.

The trend of using GDB encourages a lot of related research, including the article review study. In a literature review [3], the authors compared the performance of four types of graph database: Neo4j, OrientDB, Titan and DEX (Sparksee). The review results show that Neo4j is a superior database because of 
the optimal load workload. However, this study does not provide detailed information regarding trends in the use of gdb in any sector. In another literature review [4], comparisons were made to HyperGraphDB, Neo4j, Sparksee, AllegroGraph, and Virtuoso. However, it is not clear why this type of database was used in the comparison. Furthermore, another study [5] attempted to compare 7 GDB products based on their features, namely AP, Query Language, Usability, and Reachability. However, these studies do not provide conclusions about which products are popular and any industry that uses it.

Various scientific literature related to graph databases uses a combination of different products for analysis, such as Neo4j, Titan Graph, ArangoDB, AllegroGraph, OrientDB, and HyperGraphDB. However, it can confuse novice researchers into deciding which GDB product to study or use. In addition, researchers who study databases are also often confused as to what type of company should implement gdb. Because not all industrial sectors can apply the Graph Database effectively, graph Database will be maximized if it is used on Large Scale Data, data with related objects, or when graphic visualization is considered important [6].

Based on the above findings, this article will summarize the trend of the Graph Database in the form of a literature review, covering products that are frequently used, the industries that use them the most, and how to discuss examples of GDB in articles or research. The weakness of the database graph compared to its predecessor was not sufficiently discussed in the study [6] due to several factors. First, the comparison of advantages between graph databases and other types (e.g., rational databases) is still relatively debated. However, other studies [5][7] prove that GDB has been widely accepted in many systems. The second reason is that there is no new technology that is more solid and absolute.

In this article, the graph database review is organized into five sections, starting with the explanation of the review background in section 1. Then proceed with an explanation of the research method in Section 2 and the characteristics of the primary studies in section 3 . The results and discussion of the review literature are presented in section 4. Conclusions and insights for future studies of the Graph Database are presented at the end, Section 5.

\section{RESEARCH METHOD}

Systematic literature review (SLR) is a technique of retrieving information with related keywords or commonly referred to as information retrieval. Through the SLR process and journal reviews, researchers will find it easier to find specific information, such as when the graph database began to develop rapidly, which models are most often used, what knowledge domains are closely related to the graph database, and which companies use graph databases the most.

The framework for this SLR implementation process is illustrated in Fig. 1. In general, the SLR process is divided into three stages. First, the planning stage is carried out by studying literature related to the Graph Database (GDB) object. Researchers explore the meaning, current trends, and background of the 'graph database'. Based on this literature study, the researcher then formulates research objectives and research questions, which will be answered in Chapter. Second, conducting stage is the stage of searching for data (journal articles) that will be reviewed. This stage is carried out by determining the limits of the search in accordance with the research question submitted and setting the limit for the publication year of the article. Inclusion, exclusion, and quality assessment criteria are determined before searching for learning materials in the form of articles or papers on scientific publication portals, otherwise known as Primary Studies. The presearch stage and search strategy are detailed in Sections 2.2 and 2.3. Furthermore, the results of the data extraction process, namely a summary of the contents of each primary study, will be presented in section 2.4.

The review and search for answers to the proposed research question (RQ) will continue to be developed and reviewed during the conducting process, up to the reporting of the review results in the Reporting section.

\subsection{Objective and Research Questions}

The present research aims to find information about (1) GDB trends from a number of papers or research, (2) the application of graphical databases in the real world, (3) branches of science that use graphbased databases, and (4) What areas of the industry are raised as research issues, (5) graph database models and their usage trends. The basic mind map of the Research Question is shown in Fig. 2.

The graph is an object notation used to describe a theory or algorithm [8]. However, the term graph has many derivative terms that are difficult to distinguish from one another. This often happens to beginners who are just hearing the term "graph" because there is no definite agreement on the definition of a graph. For example, the terms graph in "graph mining" and "graph modeling" have slightly different meanings. On this basis, the authors create a taxonomy (section 4.2) like the SLR [9] to map existing terms. However, this research will only discuss graph databases, or in other words, databases based on graph theory or its derivative concepts. 


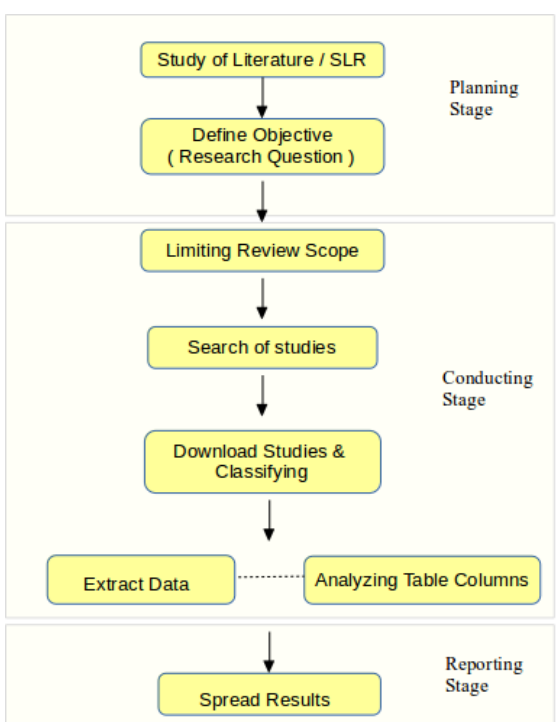

Fig. 1. Research Method of SLR

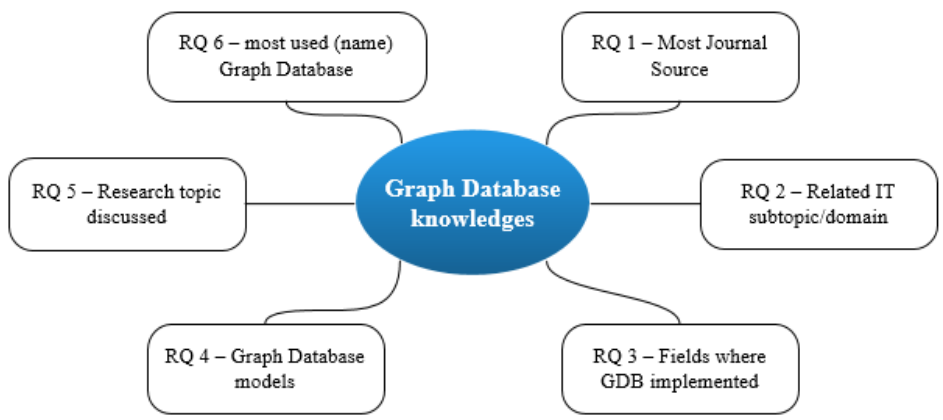

Fig. 2. Research Question's Mind Map model

Table 1 provides a description of the determination of the Research Question (RQ) based on the objectives to be achieved. RQ1 aims to find journal sources and assist searches in research on graph databases. Furthermore, RQ2 aims to cluster the IT scientific relations that are closely related to GDB. RQ3 aims to find out what types of industries or business fields implement graph-based databases in their IT systems. Take into consideration that the activities or trends related to Graphics have been developing since the first half of the nineties, but then this topic disappeared. For this reason, in RQ4, we try to summarize in the discussion which models are still valid. In RQ5 and RQ6, the researcher summarizes trends from the problem domain and trends in the use of several GDB products.

Table 1. Research Questions List

\begin{tabular}{|c|c|c|}
\hline ID & Research Question & Motivation \\
\hline RQ1 & $\begin{array}{l}\text { What journals have published many } \\
\text { articles on graph databases? }\end{array}$ & $\begin{array}{l}\text { To find out what journals have published articles on } \\
\text { graph databases }\end{array}$ \\
\hline RQ2 & $\begin{array}{l}\text { What IT constellation are related to } \\
\text { published articles or papers on graph } \\
\text { databases }\end{array}$ & $\begin{array}{l}\text { To find the IT field are discussed in the } \\
\text { article/paper/research related graph database }\end{array}$ \\
\hline RQ3 & $\begin{array}{l}\text { What types of industries use graph-based } \\
\text { databases? }\end{array}$ & $\begin{array}{l}\text { To explore the types of industries that apply graph- } \\
\text { based databases in their IT systems. }\end{array}$ \\
\hline RQ4 & $\begin{array}{l}\text { What have models from the Graph } \\
\text { Database been reviewed? }\end{array}$ & $\begin{array}{l}\text { To find out what models from the Graph Database } \\
\text { have been discussed }\end{array}$ \\
\hline RQ5 & $\begin{array}{l}\text { What is the main objective emphasized } \\
\text { by the author in the paper on graph } \\
\text { database? }\end{array}$ & $\begin{array}{l}\text { To find out the motivation or what researchers do in } \\
\text { the articles/papers/research related to the Graph } \\
\text { Database }\end{array}$ \\
\hline RQ6 & $\begin{array}{l}\text { What are the most commonly used Graph } \\
\text { Database products? }\end{array}$ & $\begin{array}{l}\text { To find out which type of Graph Database is most } \\
\text { popularly used }\end{array}$ \\
\hline
\end{tabular}




\subsection{Search Strategies}

Source: Primary Study search sources are portals of scientific articles such as ACM, IEEE, Science Direct, Springer, and other sources found to be relevant. Research Keywords: As input, keywords are needed so that the output that appears is only in accordance with the topic. We identify keywords based on the Research Question above, namely: "Graph database". The stages of searching for research articles are described in Table 2.

Table 2. Source article search stage

\begin{tabular}{cl}
\hline Stage & \multicolumn{1}{c}{ Source } \\
\hline Stage 1 & Searching with keyword "graph database"(RQ1 s/d RQ6) \\
Stage 2 & $\begin{array}{l}\text { Searching with keyword "graph database"(RQ1 s/d RQ6), "graph database model for the } \\
\text { industry" (RQ3), }\end{array}$ \\
Stage 3 & $\begin{array}{l}\text { Searching with keyword "graph", "graph model", "large-scale network database" (RQ4), } \\
\text { "NoSQL" (RQ6) }\end{array}$ \\
Stage 4 & $\begin{array}{l}\text { Searching with keyword "graph database"(RQ1 s/d RQ6) only on the papers titles, } \\
\text { keywords, and abstracts }\end{array}$ \\
Stage 5 & $\begin{array}{l}\text { Searching with keyword "graph", "graph model" (RQ1 s/d RQ6), "database model for the } \\
\text { industry" (RQ3), "graph model" (RQ4) only on the papers titles, keywords, and abstracts }\end{array}$ \\
Stage 6 & $\begin{array}{l}\text { Searching with the keyword "large-scale network database" (RQ4), "NoSQL" (RQ6) only } \\
\text { on the papers titles, keywords, and abstracts }\end{array}$ \\
Stage 7 & Exclude studies that are invalid and duplicate \\
Stage 8 & Implement inclusion/exclusion criteria \\
Stage 9 & Reviewing the selected studies, where necessary, inclusion/exclusion criteria were applied \\
\hline
\end{tabular}

Search strings are constructed based on research questions using general keywords, such as in Stage 1. The search is then continued using more specific keywords in Stages 2 and 3. Based on the search process in Stage 1 to Stage 3, the resulting output still raises data (research title) that is not relevant to this research. Based on the search process in Stage 1 to Stage 3, the resulting output still raises data (research title) that is not relevant to this research. This is probably due to two factors; first, the ambiguity of the "graph" previously described in 2.1 was not taken into account. Second, the relevance of keywords or abstracts to the content of each paper from the search results is not taken into account, although sometimes the factor of fulfilling specific requirements by digital libraries causes the embedding of inappropriate keywords or phrases. Based on this reason, searches in stages 4-7 are carried out using secondary keywords that are more specific to digital library portals/sources, such as:

\section{"Graph database", or "graph model", or "NoSQL", or "Large-scale network" or "big data implementation" or "database model for industry".}

\subsection{Selection of Studies}

Study selection is made by eliminating studies that are not written in English, less than 4 pages, and articles that do not contain the word "database" in the content of the writing. Because if the search is carried out only by using the word "graph" or "database", then the content of the research in the search results will not match the research question and inclusion criteria that have been set.

This literature study focuses on the current condition or development of the topic. Therefore, researchers limit the selection only to articles published at least in 2010 and prioritize the publication of the last five years. Researchers have adjusted the search process (Table 2) with the inclusion and exclusion criteria proposed in Tables $3 \& 4$.

\subsection{Data Extraction}

In our journal search process, we selected 60 Primary Studies most relevant to our research. In each study, data extraction and field analysis were carried out. Sections or attributes are identified through the research question and researcher analysis. The six attributes shown in the Field Extraction column in Table 5 are used to answer the appropriate research questions in the RQ column.

\subsection{Quality Assessment and Thread Validity}

At the search stage of this research, not by perusing all the titles of papers published in journals. So it is possible that the relevant paper will be missed. We also did not check whether the journal quality of each selected study was indexed well at Scimagojr.com. 
This review does not exclude studies from the category of conferences (proceedings) as most reports of experience in the study are published here in the proceedings. Therefore, sources of information on industry experiences are included.

Table 3. Paper or article criteria

\begin{tabular}{ll}
\hline No. & \multicolumn{1}{c}{ Inclusion } \\
\hline 1. & Study in either industrial or academic domains \\
2. & $\begin{array}{l}\text { Studies contain discussions, performance } \\
\text { comparisons, performances in social networks, social } \\
\text { media models, database techniques on social media }\end{array}$ \\
3. & $\begin{array}{l}\text { Studies for the implementation area of big data, data } \\
\text { science, etc. }\end{array}$ \\
4. & $\begin{array}{l}\text { For duplicate publications from the same study, only } \\
\text { the most complete and most recent included }\end{array}$
\end{tabular}

Table 4. Paper or article exclusion criteria

\begin{tabular}{ll}
\hline No. & \multicolumn{1}{c}{ Exclusion } \\
\hline 1. & $\begin{array}{l}\text { Studies that do not discuss } \\
\text { database or graph theory or graph } \\
\text { database }\end{array}$ \\
2. & $\begin{array}{l}\text { Which focuses on the concept of } \\
\text { graph, or tracing a proposed }\end{array}$ \\
algorithm or inherit graph theory. \\
3. & Which leads to graph mining. \\
4. & $\begin{array}{l}\text { Which focuses on the discussion } \\
\text { of relational databases }\end{array}$ \\
\hline
\end{tabular}

Table 5. Attributes to generate

\begin{tabular}{lll}
\hline No. & Field Extraction & RQ \\
\hline 1. & Name of Journal & RQ1 \\
2. & Subtopic of Journal & RQ2, RQ3 \\
3. & Essentials of content (Comparison/Review/System & RQ5 \\
& Approach/Classification/) & RQ1 to RQ6 \\
4. & Year published & RQ3 \\
5. & Industry/Fields Type of Usage & RQ4, RQ6 \\
6. & Graph Database name & \\
\hline
\end{tabular}

\section{CHARACTERIZATION OF SELECTED STUDIES}

Based on the previous search strategy, some of the research obtained was then grouped, as shown in Tables 6 and 7. The research obtained tends to focus on research areas and social media, as well as how database modeling with graphics is more suitable for unstructured datasets on backend servers of social media such as Facebook, Yahoo, and Amazon [10]. Such modeling of the web is related to the effectiveness of web searches [11].

Based on the search results with the keyword "graph database," the products discussed show different implementation trends. For example, the NoSQL type database is used in building applications for tourist navigation [12] indexing queries [13], developing applications [14], visualizing using GDB and LDA [15], and designing and implementing NoSQL for tracking applications [16]. The primary studies we analyzed vary widely, ranging from studies that discuss in general graph databases, such as descriptive studies [11], comparative studies [6][17][18], literature reviews and surveys [19][20], to studies that discuss in particular, such as the article on partition graph [21], new framework or model [22], and graph for machine learning implementation [23][24]. In general, few studies offer system improvements, such as through queries [25][26] or through algorithms [27][28][29].

Table 6. Number of papers selected per source

\begin{tabular}{llll}
\hline \multicolumn{1}{c}{ Query Res } & $\begin{array}{l}\text { Stage 1 }+ \\
\text { Stage 4 }\end{array}$ & $\begin{array}{l}\text { Stage 2 }+ \\
\text { Stage 5 }\end{array}$ & $\begin{array}{l}\text { Stage 3+ } \\
\text { Stage 6 }\end{array}$ \\
\hline ACM & 3 & 3 & 4 \\
IEEE & 7 & 3 & 7 \\
Springer & 9 & 5 & 2 \\
ScienceDirect & 1 & 0 & 1 \\
Other & 3 & 2 & 10 \\
\hline Total & $\mathbf{2 3}$ & $\mathbf{1 3}$ & $\mathbf{2 4}$ \\
\hline
\end{tabular}

The analysis of research publication trends on graph databases over the past decade is described in Fig. 3. The highest number of publications was in 2019, with 14 research titles, followed by nine studies in 2017 and 2018. In comparison, the least number of publications was in 2010. 


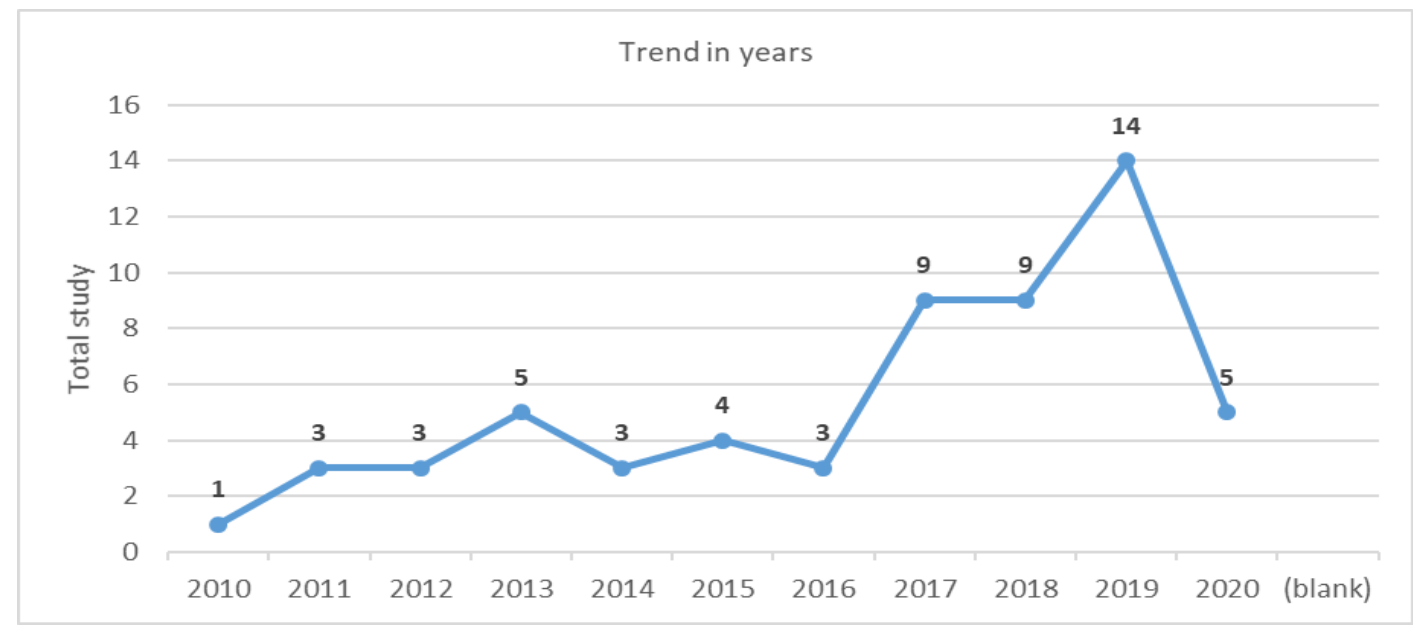

Fig. 3. Research year trends in graph database studies

Fig. 4 depicts a number of the journals we refer to, including Science Direct, ACM, Springer, IEEE, semantic scholars, and arXiv. Most articles related to the graph database were from IEEE with 17 articles, while arXiv [30] and Open Proceedings portal [31] were the portal sources that published the least related articles. In second place is the Springer link with 16 articles, while other portals such as ACM and semantic scholars accounted for $32 \%$ of the study. We also consider classifying an article discussing multi-product GDB. If there is a survey or comparison research article that contains more than one GDB product, the researcher analyzes them separately.

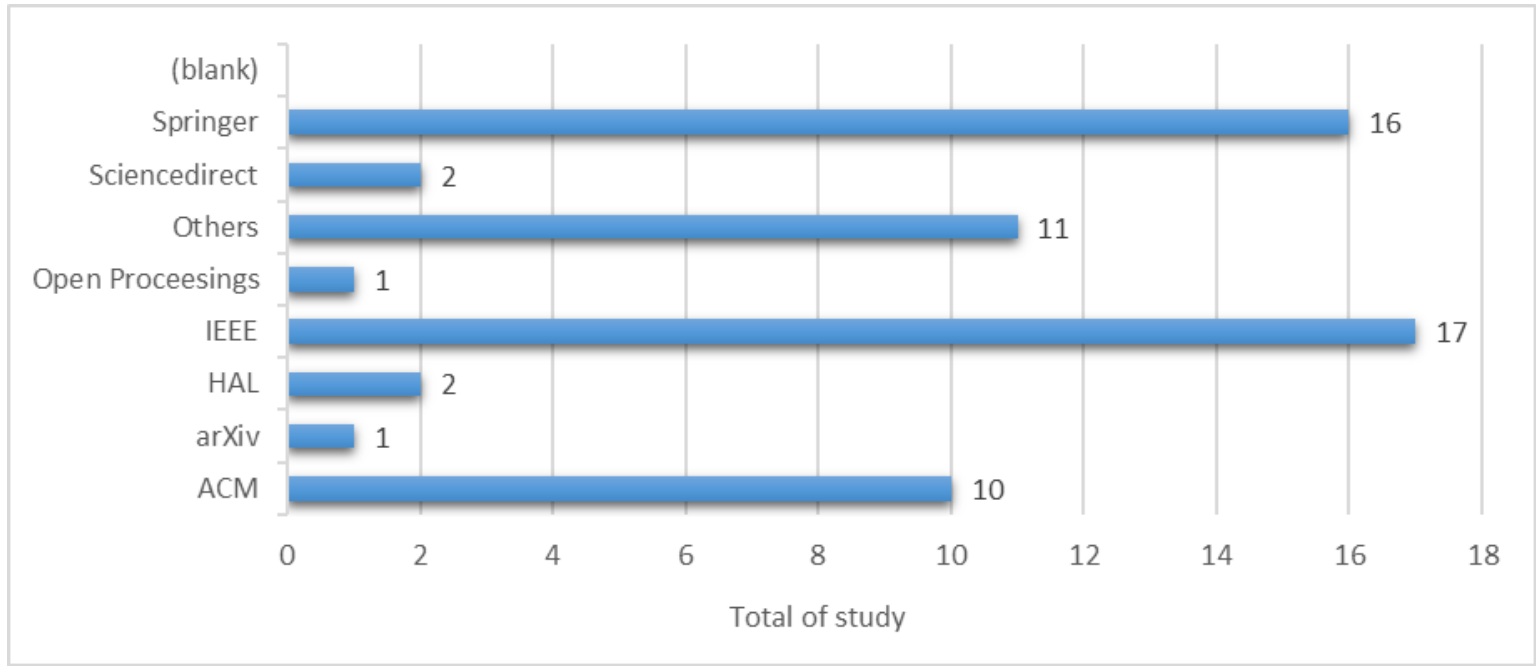

Fig. 4. Distribution of Journal portals

\section{RESULT AND DISCUSSION}

\subsection{Database Evolution}

The development of more and more complex data affects the shape of the database [7, 32]. In the early era of computerization, data storage was in the form of flat files, which were a single set of data, such as files on a separate computer. Then the more sophisticated the computer brain became, the database was hierarchical when the data could then be inherently linked. This type of network database then refines the hierarchy, where the linkage between data becomes two-way and has been the basis of relational databases since the 1970s [1]. Relational Databases, which were only globalized in the 1980s, were fundamental to data processing technologies for the last decade. The ability to handle large amounts of data is accomplished with a new table for each new object. Adding data does not affect the scheme, so processing is only a matter of speed. A set of Tables in a relational database can also be broken down into datasets. With these capabilities, RDMS becomes standardized in the industry [33].

The era of big data, which began when data was no longer very large but so complex, was no longer suitable for existing RDMS. Database operations can no longer describe a million sets of data objects with 
thousands of associated nodes. This affects the realm of information analysis the most. The Graph database (GD) then appears to answer this. Departing from graph theory that has existed since the 1980s until now, it has become the main guide for database concepts on large-scale networks such as social media, news portals, etc.

\subsection{Taxonomy}

As explained in section 2, one of the aims of this systematic literature review is to propose taxonomies and classify the related research literature into categories. We thoroughly summarize the topic of graph databases as shown in Fig. 5 and will be disclosed in Section 4.3, RQ5.

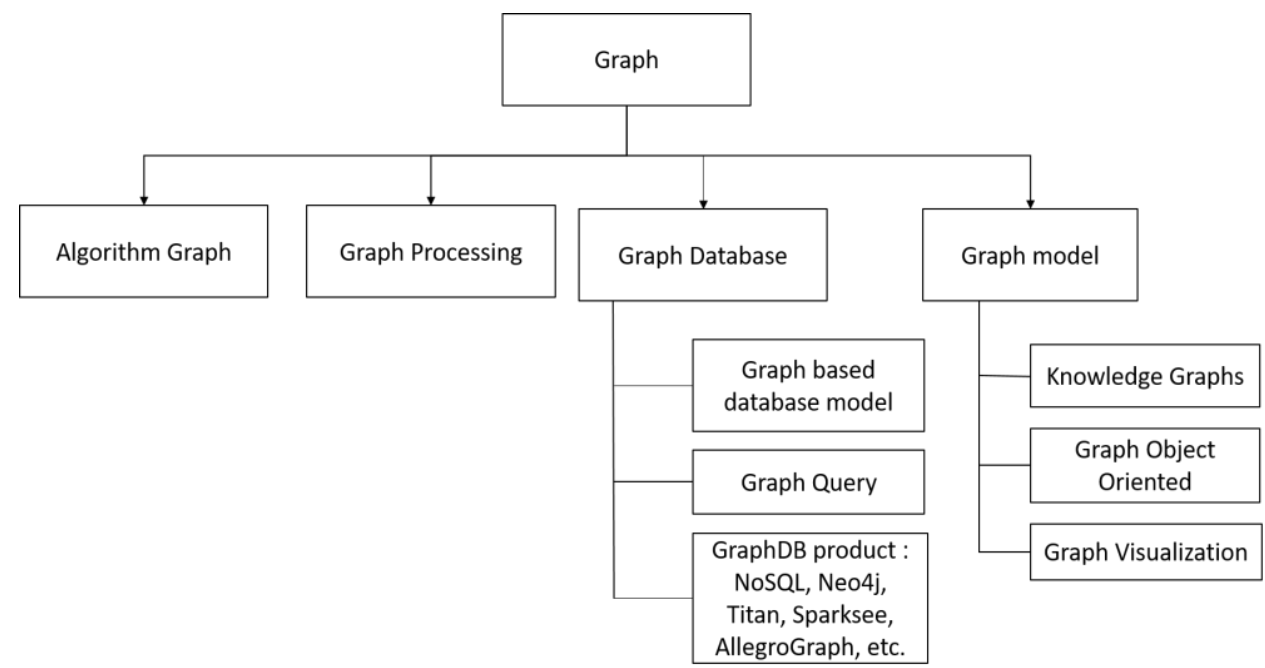

Fig. 5. Taxonomy of graph knowledge

\subsection{Research Results}

RQ1 from the process of data extraction and analysis on each study, it is known that many journals and conferences accommodate graph-related publications. The two most related conferences are the International Conference on Very Large Data Bases and the International conference on data engineering. Publication of these two conferences is accessible from the IEEE and ACM. Of the 60 primary studies, five were published in Springer's New Trends in Databases and Information Systems.

$R Q 2$ : Database is a science that has become increasingly detailed and specific. Scientific symbiosis has occurred so that it is not only in one constellation. From the literature review, the Graph database often falls into the subtopic or category of Software Engineering [34, 35], Parallel Computing [27, 36], and Big Data subtopic as in [19], [37]. The Web and the Internet with the Social Network sub-field are variations of the scientific field that accommodate a lot of research like this.

$R Q 3:$ There are two types of graph application, namely in the IT sector and the non-IT field. We discuss below the ones most frequently by previous research review. After we separated IT sectors from analysis, Fig. 6a shows the percentage of field distribution based on primary studies where GDB was implemented. Fig. 6b maps the three most sectors from Fig. 6a. Besides the general sector, academic research [38, 39] and social network topics [25, 40, 41] are commonly using Graph databases for their data processing. In the most private sector, researchers in Transportation really need Graph processing, such as to simulate traffic management [42], find the best route like [43]. Another area that is often used for graph databases is the Geographical sector, refer to publications [44, 45] and [46]. Ten titles on studies, including [47, 48, 49] take works that could be implemented in all subjects or areas. It means that GDB is really sophisticated to not be taken technology in nowadays. From another study, below are areas that frequently use graph databases.

Social Networks. For social networks tends to the application: nodes are people or groups, whereas links show the relationships or flow between nodes. Some examples are friendships, business relationships, sexual contact patterns, research networks (collaboration, co-authorship), communication records (e-mail, phone calls, e-mail), computer networks, and national security [50, 51]. This topic is highly developed in the subtopics of social network analysis or in visualization and data processing techniques for these networks.

Biological Tissue. This paper [33, 52] represents biological information that volume, management, and analysis have become issues due to the need to automate the data matching process. An example is abroad genomics, where networks occur in the regulation of genes, metabolic pathways, chemical structures, agar maps, and homologous relationships between species [Graves 
http://www.xweave.com/people/mgraves/pubs/]. Other examples of biological tissue, such as modeling of food webs and neural networks.

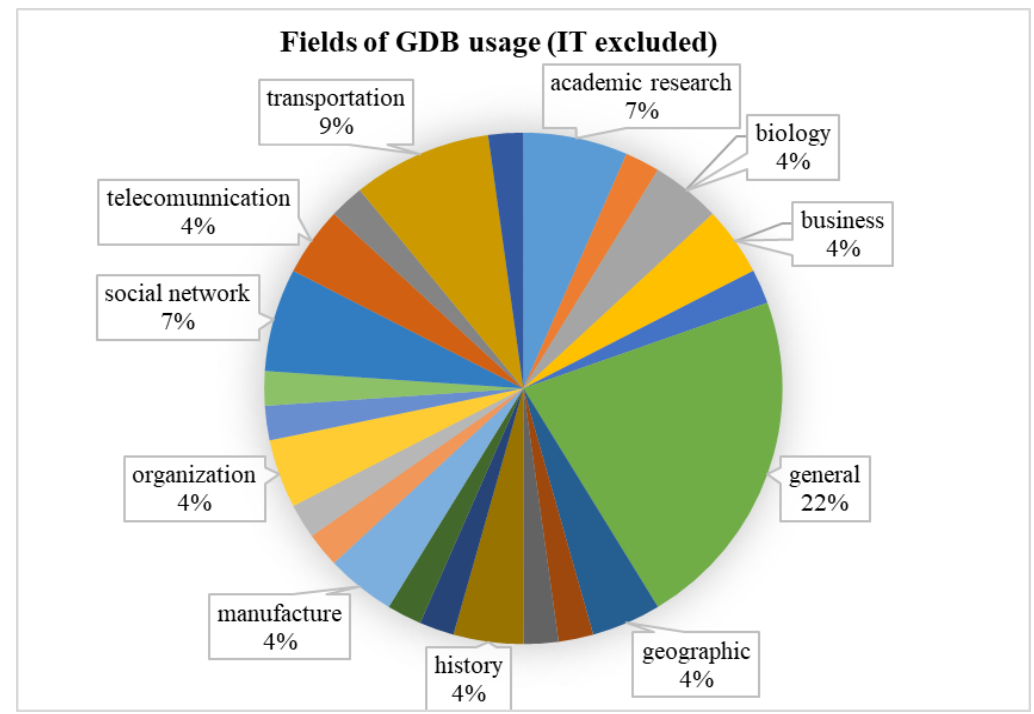

Fig. 6a. Fields distribution on studies where GDB implemented

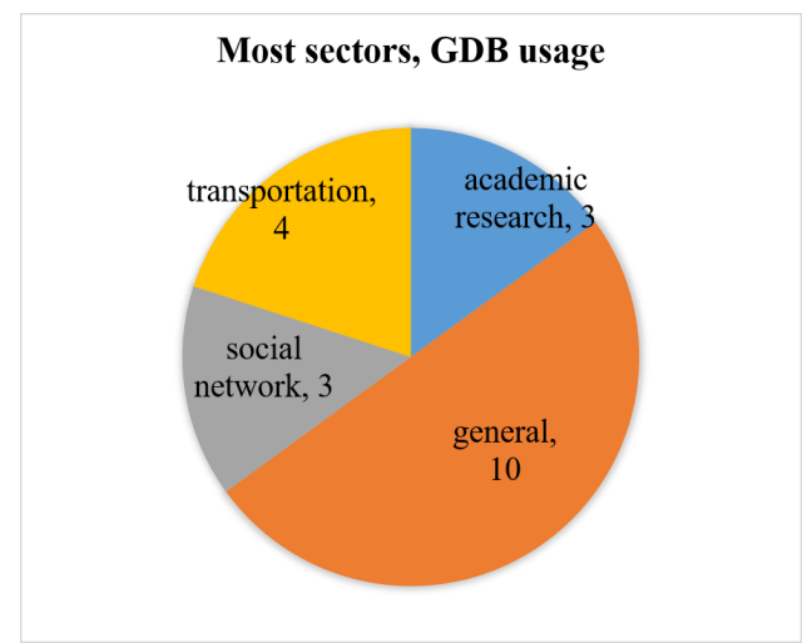

Fig. 6b. Top 3 sector based on studies

Information Networks. Researches in the information networks area [31, 53] discussed through various models. Relationship models that represent the flow of information, citations among academic papers, or the World Wide Web (hypertext, hypermedia). Another model, i.e., peer-to-peer networks visualization, relationships between classes of words in the thesaurus, and preference networks. The car industry has used graphs to try to solve the routing problem in automated vehicles [54].

Enterprise Data. Enterprise data researches [23, 25, 27] are one of the largest absorbing areas of GDB implementation. Data modeling as a graph is not limited to scientific data or web data; we can even model anything as a graph. The advantage of using graphs is the ability to represent more complex data models and support dynamic schemas. In particular, graph databases have proven successful for companies that store their product data [16], financial data, and industrial data hierarchically.

RQ4: Models from graph-based databases: Distributed Graph Databases such as Neo4j, Key-Value based databases such as Redis, OrientDB, Document-based Databases such as MongoDB, Firebase Realtime Database, or Map / Reduce Graph.

RQ5: Our taxonomy creation methodology was based on the research trends in the last few years discussed by the Primary studies' author. After careful review of the selected papers, we developed our proposed taxonomy, in which we classified the studies into four major categories related to the Graph terms: Graph Algorithm, Graph Processing, Graph Database, and Graph model. The first category, Graph algorithms, includes studies that develop the existing graph method, involving the proposed algorithms [55], 
searching algorithm [36], or proposed system [56]. The Graph Processing category includes studies comprising tools for graph data [22], how much scale of data, large data processing [27], [57]. The third category includes studies containing new approaches to the Graph Database, including papers related to graph query [13], graph base database model [6, 7, 51, 58], and discussion about any tool or product of Graph Database is used. Our taxonomy was then structured, as shown in Fig. 5. Each study was placed into one category. These intersecting areas show a relationship among several studies from different categories.

Now, we present the main contributions observed in the selected studies, classified according to our taxonomy. From the study papers that we processed, we often got a discussion about the comparison between relational databases and graph databases like in [6]. Specifically for the discussion of the Graph Database itself, many researchers have studied partitioning graphs [21][59] which are usually used to speed up data reading. In addition, it is very common to examine on the query side, such as techniques for improving querying on data with graph models $[25,26,60]$.

RQ6: These findings extrapolate Fig. 7 that kinds of GraphDB widely used are NoSQL based [22] and the most used is Neo4j. Neo4j product is comprehensive database, occupy to accommodate ranging from small-scale applications to applications with millions of users, Large Data processing to Big Data implementation. Additionally, most researcher implements SparkSee (DEX) [48][57][61], ArangoDB [34, 46] for RDF store, TitanGraph [14][41][62], OrientDB [63], TigerGraph [36][64] and AllegroGraph discussed in [38][44][65], as alternative.

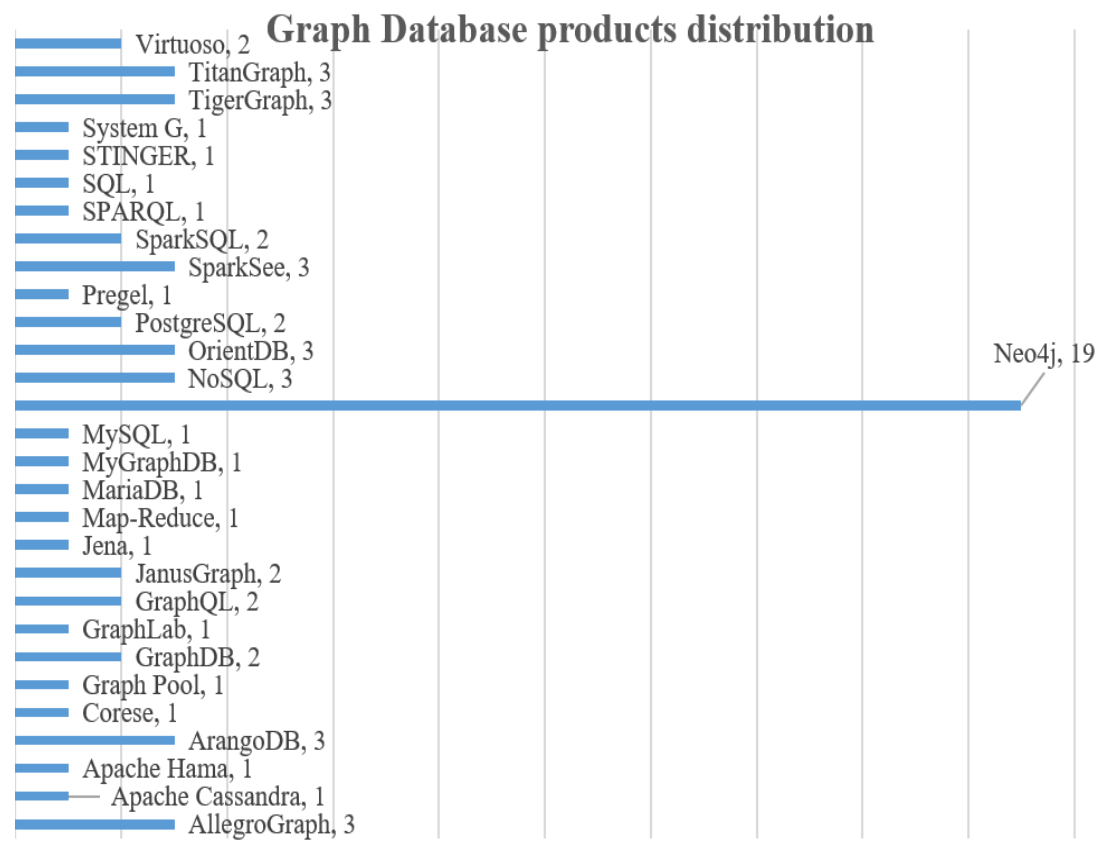

Fig. 7. GDB products used in studies

\section{CONCLUSION \& FUTURE WORKS}

Through this paper, we try to describe information about the graph database. Neo4j is the most widely used graph database product. In practice, the Neo4j database is able to handle systems with large-scale data. Therefore, the current GDB trend is in a field with enormous and growing data, namely Big Data. The results of this study can be used by future researchers as a guide to determine which sectors will implement the Graph Database. GDB is suitable for varying topics or subtopics of IT constellations such as Data Science, Semantic Web, Networking, Data Visualization, Parallel Computing, Distribution Systems, Software Engineering, etc. The research leading to this topic can examine or solve the query or partitioning side of the data model for efficiency. In addition, another research topic is the improvement of graph algorithms like PageRank. The point for future research is a new way to model graphs on large-scale network databases, as observed in the publication. For more details, a list of primary studies is presented in Table 8 . 

Vol. 7, No. 1, April 2021, pp. 43-58

Table 8. List of Primary Studies for Graph-based Database topics

\begin{tabular}{|c|c|c|c|c|c|c|}
\hline \#\# & Title & Field & Essential & Industry & $\begin{array}{l}\text { DB Graph } \\
\text { Used }\end{array}$ & Portal, Year \\
\hline 1 & $\begin{array}{c}\text { A Data Distribution Service } \\
\text { in a Hierarchical SDN } \\
\text { Architecture: } \\
\text { Implementation and } \\
\text { Evaluation [62] }\end{array}$ & $\begin{array}{l}\text { software define } \\
\text { networks }\end{array}$ & evaluation & telecommunication & $\begin{array}{l}\text { TitanGraph/ } \\
\text { Cassandara }\end{array}$ & IEEE, 2019 \\
\hline 2 & $\begin{array}{c}\text { A graph database } \\
\text { framework for covert } \\
\text { network analysis: An } \\
\text { application to the Islamic } \\
\text { state network in Europe [24] }\end{array}$ & Social Network & data modeling & intelligent & Neo4j & $\begin{array}{c}\text { Sciencedirect, } \\
2017\end{array}$ \\
\hline 3 & $\begin{array}{l}\text { A GraphQL approach to } \\
\text { Healthcare Information } \\
\text { Exchange with HL7 FHIR }\end{array}$ & GraphQL & $\begin{array}{c}\text { system } \\
\text { approach/ } \\
\text { improvement }\end{array}$ & health & GraphQL & HAL, 2019 \\
\hline 4 & $\begin{array}{l}\text { A performance evalution of } \\
\text { open source graph database }\end{array}$ & Testing/Evaluation & comparison & general & STINGER & ACM, 2014 \\
\hline 5 & $\begin{array}{c}\text { A Progressive Web } \\
\text { Application on Ancient } \\
\text { Roman Empire Coins and } \\
\text { Relevant Historical } \\
\text { Figs with Graph Database } \\
\text { [34] }\end{array}$ & PWA & $\begin{array}{l}\text { system } \\
\text { integration }\end{array}$ & history & ArangoDB & $\begin{array}{l}\text { Springer, } \\
2018\end{array}$ \\
\hline 6 & $\begin{array}{l}\text { A Selection Process of } \\
\text { Graph Databases Based on } \\
\text { Business Requirements }\end{array}$ & Graph database & comparison & general & $\begin{array}{l}\text { Neo4j, } \\
\text { JanusGraph, } \\
\text { TigerGraph }\end{array}$ & $\begin{array}{l}\text { Springer, } \\
2020\end{array}$ \\
\hline 7 & $\begin{array}{l}\text { A semantic graph database } \\
\text { for the interoperability of } \\
\text { 3D GIS data [46] }\end{array}$ & $\begin{array}{c}\text { Visualization. 3D } \\
\text { Model }\end{array}$ & $\begin{array}{c}\text { system } \\
\text { improvement }\end{array}$ & GIS & ArangoDB & $\begin{array}{l}\text { Springer, } \\
2020\end{array}$ \\
\hline 8 & $\begin{array}{l}\text { A Survey and Comparison } \\
\text { of Relational and Non- } \\
\text { Relational Database [17] }\end{array}$ & $\begin{array}{l}\text { Software } \\
\text { Engineering }\end{array}$ & comparison & general & NoSQL & Others, 2012 \\
\hline 9 & $\begin{array}{c}\text { Achieving Effective and } \\
\text { Efficient Attributed Graph } \\
\text { Data Management using } \\
\text { Lucene [61] }\end{array}$ & Database & $\begin{array}{l}\text { system } \\
\text { approach }\end{array}$ & text mining & $\begin{array}{l}\text { MyGraphDB+ } \\
\text { SparkSee, } \\
\text { Neo4j }\end{array}$ & ACM,2018 \\
\hline 10 & $\begin{array}{l}\text { Best Practices for } \\
\text { Developing Graph Database } \\
\text { Applications: A Case Study } \\
\text { Using Apache Titan [14] }\end{array}$ & Graph & $\begin{array}{l}\text { system } \\
\text { approach }\end{array}$ & $\begin{array}{l}\text { network } \\
\text { monitoring }\end{array}$ & $\begin{array}{l}\text { TitanGraph/ } \\
\text { Cassandara }\end{array}$ & Others, 2017 \\
\hline 11 & $\begin{array}{l}\text { BR-index: an indexing } \\
\text { structure for subgraph } \\
\text { matching in very large } \\
\text { dynamic graphs [13] }\end{array}$ & $\begin{array}{l}\text { Information } \\
\text { Systems }\end{array}$ & $\begin{array}{l}\text { query } \\
\text { improvement, } \\
\text { subgraph } \\
\text { indexing }\end{array}$ & internet & None & $\begin{array}{l}\text { Springer, } \\
2011\end{array}$ \\
\hline 12 & $\begin{array}{l}\text { Catch the Wind: Graph } \\
\text { Workload Balancing on } \\
\text { Cloud [21] }\end{array}$ & Algorithm & $\begin{array}{c}\text { graph } \\
\text { partitioning }\end{array}$ & cloud computing & Apache Hama & IEEE, 2013 \\
\hline 13 & $\begin{array}{c}\text { Combining Apache Spark \& } \\
\text { OrientDb to Find the } \\
\text { Influence of a Scientific } \\
\text { Paper in a Citation Network } \\
{[39]}\end{array}$ & Big Data & $\begin{array}{l}\text { software } \\
\text { architecture }\end{array}$ & scientific research & OrientDB & IEEE, 2018 \\
\hline 14 & $\begin{array}{c}\text { Comparative Analysis of } \\
\text { Relational and Graph } \\
\text { database [6] }\end{array}$ & Database & comparison & general & $\mathrm{Neo} 4 \mathrm{j}$ & Others, 2015 \\
\hline 15 & $\begin{array}{l}\text { Comparison of Relational, } \\
\text { Document and Graph } \\
\text { Database in the Context of } \\
\text { the Web Application } \\
\text { Development [18] }\end{array}$ & $\begin{array}{l}\text { Intelligent Systems } \\
\text { and Computing }\end{array}$ & comparison & web development & NoSQL & $\begin{array}{l}\text { Springer, } \\
2015\end{array}$ \\
\hline
\end{tabular}



Vol. 7, No. 1, April 2021, pp. 43-58

\begin{tabular}{|c|c|c|c|c|c|c|}
\hline \#\# & Title & Field & Essential & Industry & $\begin{array}{l}\text { DB Graph } \\
\text { Used }\end{array}$ & Portal, Year \\
\hline$\overline{16}$ & $\begin{array}{l}\text { Data Integration of Legacy } \\
\text { ERP System Based on } \\
\text { Ontology Learning from } \\
\text { SQL Scripts [20] }\end{array}$ & Ontology & review & industry & $\mathrm{Neo} 4 \mathrm{j}$ & $\begin{array}{l}\text { Springer, } \\
2019\end{array}$ \\
\hline 17 & $\begin{array}{c}\text { Detecting Evidence of } \\
\text { Fraud in the Brazilian } \\
\text { Government Using Graph } \\
\text { Databases }\end{array}$ & Fraud detection & $\begin{array}{l}\text { system } \\
\text { approach }\end{array}$ & $\begin{array}{c}\text { company } \\
\text { procurement }\end{array}$ & $\mathrm{Neo} 4 \mathrm{j}$ & $\begin{array}{l}\text { Springer, } \\
2017\end{array}$ \\
\hline 18 & $\begin{array}{c}\text { Data Quality Alerting } \\
\text { Model for Big Data } \\
\text { Analytics [37] }\end{array}$ & Big Data analytics & $\begin{array}{l}\text { proposed } \\
\text { model }\end{array}$ & general & $\mathrm{Neo} 4 \mathrm{j}$ & $\begin{array}{l}\text { Springer, } \\
2019\end{array}$ \\
\hline 19 & $\begin{array}{c}\text { Design and Implementation } \\
\text { of a Graph-Based Solution } \\
\text { for Tracking Manufacturing } \\
\text { Products [16] }\end{array}$ & graph & $\begin{array}{c}\text { system } \\
\text { improvement }\end{array}$ & manufacture & OrientDB & $\begin{array}{l}\text { Springer, } \\
2019\end{array}$ \\
\hline 20 & $\begin{array}{l}\text { DEX: A high performance } \\
\text { graph database management } \\
\text { system. }\end{array}$ & $\begin{array}{l}\text { Data, Software } \\
\text { Engineer }\end{array}$ & $\begin{array}{c}\text { graph database } \\
\text { system }\end{array}$ & general & DEX & IEEE, 2011 \\
\hline 21 & $\begin{array}{l}\text { Distributed GraphLab: A } \\
\text { Framework for Machine } \\
\text { Learning \& Data Mining in } \\
\text { the Cloud [23] }\end{array}$ & Machine Learning & $\begin{array}{l}\text { graph-parallel } \\
\text { computation, } \\
\text { the proposed } \\
\text { framework }\end{array}$ & e-commerce & GraphLab & ACM, 2012 \\
\hline 22 & $\begin{array}{c}\text { Efficient Snapshot Retrieval } \\
\text { over Historical Graph Data } \\
\text { [53] }\end{array}$ & Database, big data & $\begin{array}{l}\text { graph } \\
\text { databases, } \\
\text { system } \\
\text { proposed } \\
\text { model }\end{array}$ & history & Graph Pool & IEEE, 2013 \\
\hline 23 & $\begin{array}{c}\text { Employing graph databases } \\
\text { as a standardization model } \\
\text { towards } \\
\text { addressing heterogeneity } \\
\text { [28] }\end{array}$ & Database & $\begin{array}{l}\text { approach } \\
\text { technique }\end{array}$ & $\begin{array}{c}\text { semantic web, big } \\
\text { data }\end{array}$ & $\mathrm{Neo} 4 \mathrm{j}$ & IEEE, 2016 \\
\hline 24 & $\begin{array}{c}\text { Explore Efficient Data } \\
\text { Organization for Large } \\
\text { Scale Graph Analytics and } \\
\text { Storage [27] }\end{array}$ & $\begin{array}{c}\text { Parallel } \\
\text { Computing, Big } \\
\text { Data }\end{array}$ & $\begin{array}{c}\text { system } \\
\text { improvement }\end{array}$ & organization & System G & Others, 2014 \\
\hline 25 & $\begin{array}{l}\text { Exploring Large Scholarly } \\
\text { Networks with Hermes [31] }\end{array}$ & $\begin{array}{l}\text { scientific } \\
\text { publications }\end{array}$ & $\begin{array}{l}\text { approach } \\
\text { technique }\end{array}$ & network data & JanusGraph & $\begin{array}{c}\text { Open } \\
\text { Proceedings, } \\
2018\end{array}$ \\
\hline 26 & $\begin{array}{l}\text { Fast Grid Splitting } \\
\text { Detection for N-1 } \\
\text { Contingency } \\
\text { Analysis by Graph } \\
\text { Computing [36] }\end{array}$ & parallel computing & $\begin{array}{l}\text { approach } \\
\text { algorithm }\end{array}$ & transportation & TigerGraph & IEEE, 2019 \\
\hline 27 & $\begin{array}{c}\text { From Punched Cards to Big } \\
\text { Data: A Social History of a } \\
\text { Database Populism }\end{array}$ & Big Data & review & academic research & SQL & IEEE, 2012 \\
\hline 28 & $\begin{array}{l}\text { General Model for Tracking } \\
\text { Manufacturing Products } \\
\text { Using Graph Databases [63] }\end{array}$ & graph & $\begin{array}{c}\text { system } \\
\text { improvement }\end{array}$ & manufacturing & OrientDB & $\begin{array}{l}\text { Springer, } \\
2018\end{array}$ \\
\hline 29 & $\begin{array}{c}\text { Geographic Data in a Graph } \\
\text { Oriented Database [45] }\end{array}$ & geographic data & comparison & geographic & PostgreSQL & IEEE, 2017 \\
\hline 30 & $\begin{array}{l}\text { Graph based Platform for } \\
\text { Electricity Market Study, } \\
\text { Education and Training [64] }\end{array}$ & Graph computing & $\begin{array}{c}\text { system } \\
\text { improvement }\end{array}$ & $\begin{array}{c}\text { marketing } \\
\text { (electricity market) }\end{array}$ & TigerGraph & IEEE, 2018 \\
\hline 31 & $\begin{array}{c}\text { Graph Database } \\
\text { Applications and Concept } \\
\text { with Neo4j [47] }\end{array}$ & $\begin{array}{l}\text { Information } \\
\text { Systems }\end{array}$ & comparison & general & Neo4j & others, 2013 \\
\hline 32 & $\begin{array}{c}\text { Graph Database Approach } \\
\text { for Data Storing, } \\
\text { Presentation and }\end{array}$ & Database & comparison & web & $\mathrm{Neo} 4 \mathrm{j}$ & IEEE, 2019 \\
\hline
\end{tabular}



Vol. 7, No. 1, April 2021, pp. 43-58

\begin{tabular}{|c|c|c|c|c|c|c|}
\hline \#\# & Title & Field & Essential & Industry & $\begin{array}{l}\text { DB Graph } \\
\text { Used }\end{array}$ & Portal, Year \\
\hline 33 & $\begin{array}{c}\text { Manipulation } \\
\text { IASelect: Finding Best-fit } \\
\text { Agent Practices in } \\
\text { Industrial CPS Using Graph } \\
\text { Databases [51] }\end{array}$ & Querying & $\begin{array}{l}\text { approach } \\
\text { technique }\end{array}$ & systems agent & $\mathrm{Neo} 4 \mathrm{j}$ & IEEE, 2019 \\
\hline 34 & $\begin{array}{l}\text { IBM Db2 Graph: } \\
\text { Supporting Synergistic and } \\
\text { RetrofitTable Graph Queries } \\
\text { Inside IBM Db2 }\end{array}$ & Network & $\begin{array}{c}\text { system } \\
\text { improvement }\end{array}$ & database & ArangoDB & ACM, 2020 \\
\hline 35 & $\begin{array}{l}\text { Implementation of FOAF, } \\
\text { AIISO, and DOAP } \\
\text { ontologies for creating an } \\
\text { academic community } \\
\text { network using semantic } \\
\text { frameworks [38] }\end{array}$ & Semantic Web & $\begin{array}{c}\text { system } \\
\text { improvement }\end{array}$ & academic research & $\begin{array}{l}\text { AllegroGraph } \\
\text { \& SPARQL }\end{array}$ & Others, 2019 \\
\hline 36 & $\begin{array}{l}\text { Improving the OEEU's data- } \\
\text { driven technological } \\
\text { ecosystem's interoperability } \\
\text { with GraphQL [29] }\end{array}$ & Data-driven & $\begin{array}{c}\text { system } \\
\text { improvement }\end{array}$ & organization & GraphQL & ACM, 2017 \\
\hline 37 & $\begin{array}{l}\text { A Study of Blockchain- } \\
\text { based on Graph Database } \\
\text { for Software Quality }\end{array}$ & $\begin{array}{l}\text { Software Quality } \\
\text { Measurement }\end{array}$ & $\begin{array}{c}\text { quality } \\
\text { measurement }\end{array}$ & security & None & IEEE, 2018 \\
\hline & Measurement Integrity [35] & & & & & \\
\hline 38 & $\begin{array}{c}\text { K-NN queries in graph } \\
\text { databases using M-Trees } \\
{[26]}\end{array}$ & $\begin{array}{c}\text { Pattern } \\
\text { Recognition }\end{array}$ & $\begin{array}{c}\text { query } \\
\text { improvement }\end{array}$ & general & Text & $\begin{array}{l}\text { Springer, } \\
2011\end{array}$ \\
\hline 39 & $\begin{array}{l}\text { Managing and Visualizing } \\
\text { Citation Network Using } \\
\text { Graph Database and Lda } \\
\text { Model [15] }\end{array}$ & $\begin{array}{c}\text { Database } \\
\text { Visualization }\end{array}$ & $\begin{array}{c}\text { document } \\
\text { management }\end{array}$ & academic research & $\mathrm{Neo} 4 \mathrm{j}$ & ACM, 2017 \\
\hline 40 & $\begin{array}{c}\text { Managing cyber threat } \\
\text { intelligence in a graph } \\
\text { database [50] }\end{array}$ & Cyber Networks & cyber security & system agent & NoSQL & IEEE, 2018 \\
\hline 41 & $\begin{array}{c}\text { Metadata Management for } \\
\text { Data Lakes [49] }\end{array}$ & Meta Data & $\begin{array}{l}\text { system } \\
\text { approach }\end{array}$ & general & $\mathrm{Neo} 4 \mathrm{j}$ & HAL, 2019 \\
\hline 42 & $\begin{array}{c}\text { Modelling and Querying } \\
\text { Star } \\
\text { and Snowflake Warehouses } \\
\text { Using } \\
\text { Graph Databases [60] }\end{array}$ & data warehouse & $\begin{array}{c}\text { system } \\
\text { improvement }\end{array}$ & music & Neo4j, Postgre & $\begin{array}{l}\text { Springer, } \\
2019\end{array}$ \\
\hline 43 & $\begin{array}{l}\text { MSP: Multiple Sub-graph } \\
\text { Query Processing using } \\
\text { Structure-based Graph }\end{array}$ & distributed systems & $\begin{array}{l}\text { graph } \\
\text { partitioning }\end{array}$ & general & Map-Reduce & $\begin{array}{c}\text { Sciencedirect, } \\
2016\end{array}$ \\
\hline & $\begin{array}{l}\text { Partitioning Strategy and } \\
\text { Map-Reduce [59] }\end{array}$ & & & & & \\
\hline 44 & $\begin{array}{l}\text { Parallel Shortest Path Graph } \\
\text { Computations of United } \\
\text { States Road Network Data } \\
\text { on Apache Spark [43] }\end{array}$ & Big Data & $\begin{array}{l}\text { algorithm } \\
\text { solution }\end{array}$ & transportation & $\begin{array}{c}\text { GraphX } \\
+ \text { SparkSQL }\end{array}$ & $\begin{array}{l}\text { Springer, } \\
2018\end{array}$ \\
\hline 45 & $\begin{array}{l}\text { Pregel: A System for Large- } \\
\text { Scale Graph Processing [22] }\end{array}$ & $\begin{array}{l}\text { Software } \\
\text { Engineering }\end{array}$ & $\begin{array}{c}\text { proposed } \\
\text { model, cluster }\end{array}$ & algorithm & Pregel & ACM, 2010 \\
\hline 46 & $\begin{array}{c}\text { Property Hypergraphs as an } \\
\text { Attributed Predicate RDF } \\
{[55]}\end{array}$ & $\begin{array}{l}\text { RDF, Graph } \\
\text { database }\end{array}$ & $\begin{array}{l}\text { algorithm } \\
\text { approach }\end{array}$ & world bank & Jena & Others, 2015 \\
\hline 47 & $\begin{array}{l}\text { QODI: Query as Context in } \\
\text { Automatic Data Integration } \\
\text { [52] }\end{array}$ & Semantic Web & $\begin{array}{c}\text { query } \\
\text { optimization }\end{array}$ & biological data & SPARQL & $\begin{array}{l}\text { Springer, } \\
2013\end{array}$ \\
\hline 48 & $\begin{array}{c}\text { Query Optimization } \\
\text { Techniques In Graph } \\
\text { Databases [48] }\end{array}$ & Database & $\begin{array}{c}\text { query } \\
\text { optimization }\end{array}$ & general & Neo4j, DEX & Others, 2016 \\
\hline
\end{tabular}



Vol. 7, No. 1, April 2021, pp. 43-58

\begin{tabular}{|c|c|c|c|c|c|c|}
\hline \#\# & Title & Field & Essential & Industry & $\begin{array}{l}\text { DB Graph } \\
\text { Used }\end{array}$ & Portal, Year \\
\hline 49 & $\begin{array}{c}\text { RelSeeker: Relationship- } \\
\text { based Query Language in a } \\
\text { Graph Database for Social } \\
\text { Networks [25] }\end{array}$ & Database & $\begin{array}{c}\text { query } \\
\text { optimization }\end{array}$ & social network & MySQL & EEE, 2019 \\
\hline 50 & $\begin{array}{c}\text { Representation and } \\
\text { Querying of Valid Time of } \\
\text { Triples in Linked Geospatial } \\
\text { Data [44] }\end{array}$ & $\mathrm{RDF}$ & comparison & geospatial & AllegroGraph, & $\begin{array}{l}\text { Springer, } \\
2013\end{array}$ \\
\hline 51 & $\begin{array}{l}\text { Scale-out evaluation of } \\
\text { news feed retrieval } \\
\text { algorithms on Neo4j and } \\
\text { Titan clusters [41] }\end{array}$ & Newsfeed retrieval & algorithm & social network & Neo4j, Titan & ACM, 2015 \\
\hline 52 & $\begin{array}{l}\text { Semantic models in web- } \\
\text { based educational system } \\
\text { integration [65] }\end{array}$ & Semantic Web & model proof & education & $\begin{array}{l}\text { Allegrograph, } \\
\text { Corese, } \\
\text { GraphDB } \\
\text { (graphdb), } \\
\text { Virtuoso }\end{array}$ & Others, 2018 \\
\hline 53 & $\begin{array}{l}\text { Semantic Traffic Sensor } \\
\text { Data: The TRAFAIR } \\
\text { experience [42] }\end{array}$ & Data management & $\begin{array}{l}\text { approach } \\
\text { system }\end{array}$ & $\begin{array}{c}\text { traffic management } \\
\text { system }\end{array}$ & Virtuoso & Others, 2020 \\
\hline 54 & $\begin{array}{l}\text { Simulation System for } \\
\text { Combining Requests of } \\
\text { Independent Intelligent } \\
\text { Agents to Reduce the Load } \\
\text { on the Communication } \\
\text { Channel based on a Graph } \\
\text { Database using Cars as an } \\
\text { Example [54] }\end{array}$ & Auto vehicles & $\begin{array}{l}\text { algorithm } \\
\text { solution }\end{array}$ & simulation & $\mathrm{Neo} 4 \mathrm{j}$ & IEEE, 2020 \\
\hline 55 & $\begin{array}{l}\text { Thinking With Containers: } \\
\text { A Multi-Agent Retrieval } \\
\text { Approach for the } \\
\text { Case-Based Semantic } \\
\text { Search of Architectural } \\
\text { Designs }\end{array}$ & $\begin{array}{l}\text { Case-based } \\
\text { reasoning }\end{array}$ & $\begin{array}{l}\text { system } \\
\text { approach }\end{array}$ & architecture design & $\begin{array}{l}\text { GraphDB, } \\
\text { GraphML }\end{array}$ & ACM, 2017 \\
\hline 56 & $\begin{array}{l}\text { THUNDERSTORM: A } \\
\text { Tool to Evaluate Dynamic } \\
\text { Network Topologies on } \\
\text { Distributed System }\end{array}$ & distributed systems & $\begin{array}{c}\text { tool } \\
\text { evaluation }\end{array}$ & telecommunication & $\begin{array}{l}\text { Apache } \\
\text { Cassandra, } \\
\text { MariaDB }\end{array}$ & IEEE, 2019 \\
\hline 57 & $\begin{array}{l}\text { Understanding Trolls with } \\
\text { Efficient Analytics Of Large } \\
\text { Graphs in Neo4j [40] }\end{array}$ & Graph database & review & social network & $\mathrm{Neo} 4 \mathrm{j}$ & ACM, 2019 \\
\hline 58 & $\begin{array}{c}\text { Use of Graph Database for } \\
\text { the Integration of } \\
\text { Heterogeneous Biological } \\
\text { Data }\end{array}$ & Graph database & comparison & biology & $\mathrm{Neo} 4 \mathrm{j}$ & Others, 2017 \\
\hline 59 & $\begin{array}{c}\text { Use of Graph Databases in } \\
\text { Tourist Navigation } \\
\text { Application [12] }\end{array}$ & AI & $\begin{array}{l}\text { node path } \\
\text { algorithm }\end{array}$ & tourism & None & $\begin{array}{l}\text { Springer, } \\
2014\end{array}$ \\
\hline 60 & $\begin{array}{l}\text { Zooming in on NYC taxi } \\
\text { data with Portal [30] }\end{array}$ & $\begin{array}{c}\text { Graph-based } \\
\text { database models }\end{array}$ & $\begin{array}{l}\text { system } \\
\text { approach }\end{array}$ & transportation & $\begin{array}{c}\text { GraphX } \\
+ \text { SParkSQL }\end{array}$ & arXiv, 2017 \\
\hline
\end{tabular}

\section{REFERENCES}

[1] C. J. Date, "An Introduction to Database Systems," Pearson Education India, 1975.

[2] S. Patil, G. Vaswani, and A. Bhatia, "Graph Databases- An Overview," Int. J. Comput. Sci. Inf. Technol., vol. 5, no. 1 , pp. 657-660, 2014.

[3] S. Jouili and V. Vansteenberghe, "An empirical comparison of graph databases," Proc. - Soc. 2013, pp. 708-715, 2013. https://doi.org/10.1109/SocialCom.2013.106

[4] E. Germán Andrés Pérez and O. S. Pabón, “A comparison of NoSQL graph databases," 2014 9th Comput. Colomb. Conf. 9CCC 2014, pp. 128-131, 2014. https://doi.org/10.1109/ColumbianCC.2014.6955355

[5] R. Kumar Kaliyar, "Graph databases: A survey," Int. Conf. Comput. Commun. Autom. ICCCA 2015, pp. 785-790, 2015. https://doi.org/10.1109/CCAA.2015.7148480 
[6] G. Jaiswal and A. P. Agrawal, "Comparative analysis of Relational and Graph databases," OSR Journal of Engineering (IOSRJEN), vol. 3, no. 8, pp. 2250-3021, 2013.

[7] M. Besta et al., "Demystifying graph databases: Analysis and taxonomy of data organization, system designs, and graph queries," arXiv preprint arXiv: 1910.09017, 2019. https://arxiv.org/abs/1910.09017v4

[8] L. Ehrlinger and Wolfram Wöß, "Towards a definition of knowledge graphs," SEMANTiCS, vol. 48, pp. 1-4, 2016.

[9] I. Polato, R. Ré, A. Goldman, and F. Kon, "A comprehensive view of Hadoop research - A systematic literature review,” J. Netw. Comput. Appl., vol. 46, pp. 1-25, 2014. https://doi.org/10.1016/j.jnca.2014.07.022

[10] M. Buerli and C. Obispo, "The Current State of Graph Databases," Dep. Comput. Sci. Cal Poly San Luis Obispo, vol. 32, no. 3, pp. 67-83, 2012.

[11] R. McColl, D. Ediger, J. Poovey, D. Campbell, and D. A. Bader, "A performance evaluation of open source graph databases," PPAA 2014 - Proc. 2014 Work. Parallel Program. Anal. Appl., pp. 11-17, 2014. https://doi.org/10.1145/2567634.2567638

[12] A. Basiri, P. Amirian, and A. Winstanley, "Use of graph databases in tourist navigation application," Lect. Notes Comput. Sci. (including Subser. Lect. Notes Artif. Intell. Lect. Notes Bioinformatics), vol. 8583 LNCS, no. PART 5, pp. 663-677, 2014. https://doi.org/10.1007/978-3-319-09156-3 46

[13] J. Yang and J. Wei, "BR-Index: An Indexing Structure for Subgraph Matching in Very Large Dynamic Graphs," Sci. Stat. Database Manag. SSDBM 2011. Lect. Notes Comput. Sci., vol. 6809, pp. 322-331, 2011. https://doi.org/10.1007/978-3-642-22351-8_20

[14] G. Campero Durand, D. Broneske, M. Pinnecke, Saake, Gunter, and T. Spatzier, "Best Practices for Developing Graph Database Applications: A Case Study Using Apache Titan," Master Thesis, University of Magdeburg, 2017.

[15] T. Nguyen and P. Do, "Managing and visualizing citation network using graph database and LDA model," ACM Int. Conf. Proceeding Ser., vol. 2017-Decem, pp. 100-105, 2017. https://doi.org/10.1145/3155133.3155154

[16] J. Martinez-Gil, R. Stumpner, C. Lettner, M. Pichler, and W. Fragner, "Design and Implementation of a GraphBased Solution for Tracking Manufacturing Products," Commun. Comput. Inf. Sci., vol. 1064, pp. 417-423, 2019. https://doi.org/10.1007/978-3-030-30278-8_41

[17] N. Jatana, S. Puri, M. Ahuja, I. Kathuria, and D. Gosain, "A Survey and Comparison of Relational and NonRelational Database,” Int. J. Eng. Res. Technol., vol. 1, no. 6, pp. 1-5, 2012.

[18] D. Plechawska-Wójcik, Małgorzata, Rykowski, "Comparison of Relational, Document and Graph Databases in the Context of the Web Application Development," A. Grzech al. (eds.), Inf. Syst. Archit. Technol. Proc. 36th Int. Conf. Inf. Syst. Archit. Technol. - ISAT 2015 - Part I, Adv. Intell. Syst. Comput., vol. 430, pp. V-vi, 2016. https://doi.org/10.1007/978-3-319-28561-0_1

[19] K. Driscoll, From Punched Cards to "Big Data": A Social History of Database Populism, vol. 1, no. August. 2012.

[20] C. Ma, Data Integration of Legacy ERP System Based on Ontology Learning from SQL Scripts, vol. 1064. 2019. https://doi.org/10.5220/0007740602310237

[21] Z. Shang and J. X. Yu, "Catch the wind: Graph workload balancing on cloud," 2013 IEEE 29 ${ }^{\text {th }}$ Int. Conf. Data Eng. Brisbane, QLD, Australia, pp. 553-564, 2013. https://doi.org/10.1109/ICDE.2013.6544855

[22] G. Malewicz et al., "Pregel: A System for Large-Scale Graph Processing," pp. 135-145, 2010. https://doi.org/10.1145/1807167.1807184

[23] Y. Low, D. Bickson, J. Gonzalez, C. Guestrin, A. Kyrola, and J. M. Hellerstein, "Distributed GraphLab: A Framework for Machine Learning and Data Mining in the Cloud," Proc. VLDB Endow., vol. 5, no. 8, pp. 716-727, 2012. https://doi.org/10.14778/2212351.2212354

[24] A. Gutfraind and M. Genkin, "A graph database framework for covert network analysis: An application to the Islamic State network in Europe," Soc. Networks, vol. 51, pp. 178-188, 2017. https://doi.org/10.1016/j.socnet.2016.10.004

[25] J. Wu and Y. Nakamoto, "RelSeeker: Relationship-based Query Language in a Graph Database for Social Networks," 2019 6th Int. Conf. Soc. Networks Anal. Manag. Secur. SNAMS 2019, pp. 268-273, 2019. https://doi.org/10.1109/SNAMS.2019.8931872

[26] F. Serratosa, A. Solé-Ribalta, and Cortes Xavier, "K-nn Queries in Graph Databases Using M-Trees*," A. Berciano al. CAIP 2011, Part I, LNCS 6854, pp. 202-210, 2011. https://doi.org/10.1007/978-3-642-23672-3_25

[27] Y. Xia et al., "Explore Efficient Data Organization for Large Scale Graph Analytics and Storage," Proc. - 2014 IEEE Int. Conf. Big Data, IEEE Big Data 2014, pp. 942-951, 2014. https://doi.org/10.1109/BigData.2014.7004326

[28] D. Aggarwal and K. C. Davis, "Employing graph databases as a standardization model towards addressing heterogeneity," Proc. - 2016 IEEE 17th Int. Conf. Inf. Reuse Integr. IRI 2016, no. Idc, pp. 198-207, 2016. https://doi.org/10.1109/IRI.2016.33

[29] A. Vazquez-Ingelmo, J. Cruz-Benito, and F. J. García-Penalvo, "Improving the OEEU's data-driven technological ecosystem's interoperability with GraphQL," ACM Int. Conf. Proceeding Ser., vol. Part F1322, 2017. https://doi.org/10.1145/3144826.3145437

[30] J. Stoyanovich, M. Gilbride, and V. Z. Moffitt, "Zooming in on NYC taxi data with Portal," arXiv, pp. 1-8, 2017. https://arxiv.org/abs/1709.06176v1

[31] G. C. Durand et al., "Exploring large scholarly networks with HERMES," Adv. Database Technol. - EDBT, Open Proceedings, pp. 650-653, 2018. http://dx.doi.org/10.5441/002/edbt.2018.76

[32] K. L. Berg, T. Seymour and R. Goel, "History of Databases," International Journal of Management \& Information Systems (IJMIS), vol. 17, no. 1, pp. 29-36, 2013. https://doi.org/10.19030/ijmis.v17i1.7587

[33] R. Angles and C. Gutierrez, "Querying RDF data from a graph database perspective," Lect. Notes Comput. Sci., 
vol. 3532, no. c, pp. 346-360, 2005. https://doi.org/10.1007/11431053_24

[34] K. Hu and J. Zhu, "A progressive web application on ancient roman empire coins and relevant historical Figs with graph database," vol. 11197 LNCS. Springer International Publishing, 2018. https://doi.org/10.1007/978-3-03001765-1_26

[35] D. Kim Stephen and H. Kim Ailee, "A Study of Blockchain based on Graph Database for Software Quality Measurement Integrity," 9th Int. Conf. Inf. Commun. Technol. Converg. ICT Converg. Powered by Smart Intell. ICTC 2018, pp. 1457-1460, 2018. https://doi.org/10.1109/ICTC.2018.8539657

[36] Y. Zhu, L. Shi, R. Dai, and G. Liu, "Fast grid splitting detection for n-1 contingency analysis by graph computing," arXiv, pp. 673-677, 2019. https://doi.org/10.1109/ISGT-Asia.2019.8880879

[37] E. Gyulgyulyan, J. Aligon, F. Ravat, and H. Astsatryan, "Data Quality Alerting Model for Big Data Analytics," Commun. Comput. Inf. Sci., vol. 1064, pp. 489-500, 2019. https://doi.org/10.1007/978-3-030-30278-8_47

[38] H. Ahuja and R. Sivakumar, "Implementation of FOAF, AIISO and DOAP ontologies for creating an academic community network using semantic frameworks," Int. J. Electr. Comput. Eng., vol. 9, no. 5, pp. 4302-4310, 2019. https://doi.org/10.11591/ijece.v9i5.pp4302-4310

[39] T. P. Hong and P. Do, "Combining Apache Spark OrientDb to Find the Influence of a Scientific Paper in a Citation Network," Proc. 2018 10th Int. Conf. Knowl. Syst. Eng. KSE 2018, pp. 113-117, 2018. https://doi.org/10.1109/KSE.2018.8573432

[40] D. Allen et al., "Understanding trolls with efficient analytics of large graphs in Neo4j," Lect. Notes Informatics (LNI), Proc. - Ser. Gesellschaft fur Inform., pp. 377-396, 2019. https://dx.doi.org/10.18420/btw2019-23

[41] S. Schlicht, "Scale-out evaluation of news feed retrieval algorithms on Neo4j and Titan clusters," no. April, 2015.

[42] F. Desimoni, S. Ilarri, L. Po, F. Rollo, and R. Trillo-Lado, "Semantic traffic sensor data: The TRAFAIR experience," Appl. Sci., vol. 10, no. 17, 2020. https://doi.org/10.3390/app10175882

[43] Y. Arfat, R. Mehmood, and A. Albeshri, Parallel Shortest Path Graph Computations of United States Road Network Data on Apache Spark, vol. 224. Springer International Publishing, 2018. https://doi.org/10.1007/978-3319-94180-6 30

[44] K. Bereta, P. Smeros, and M. Koubarakis, "Representation and querying of valid time of triples in linked geospatial data," Lect. Notes Comput. Sci. (including Subser. Lect. Notes Artif. Intell. Lect. Notes Bioinformatics), vol. 7882 LNCS, pp. 259-274, 2013. https://doi.org/10.1007/978-3-642-38288-8_18

[45] E. Roberto, M. T. de Holanda, A. P. F. de Araujo, and M. Victorino, "Geographic data in a graph oriented database: A study with Neo4j and PostgreSQL,” pp. 1-6, 2017. https://doi.org/10.23919/CISTI.2017.7975999

[46] E. S. Malinverni, B. Naticchia, J. L. Lerma Garcia, A. Gorreja, J. Lopez Uriarte, and F. Di Stefano, "A semantic graph database for the interoperability of 3D GIS data," Appl. Geomatics, 2020. https://doi.org/10.1007/s12518020-00334-3

[47] J. J. Miller, "Graph database applications and concepts with Neo4j," Proc. South. Assoc. Inf. Syst. Conf. Atlanta, GA, USA, vol. 2324, pp. 36, 2013.

[48] A. Ben Ammar, "Query Optimization Techniques in Graph Databases," Int. J. Database Manag. Syst., vol. 8, no. 4, pp. 01-14, 2016. https://doi.org/10.5121/ijdms.2016.8401

[49] F. Ravat and Y. Zhao, "Metadata Management for Data Lakes," European Conference on Advances in Databases and Information System, Springer, 2019. https://doi.org/10.1007/978-3-030-30278-8_5

[50] S. Lee, H. Cho, N. Kim, B. Kim, and J. Park, "Managing Cyber Threat Intelligence in a Graph Database: Methods of Analyzing Intrusion Sets, Threat Actors, and Campaigns,” 2018 Int. Conf. Platf. Technol. Serv. PlatCon 2018, pp. 1-6, 2018. https://doi.org/10.1109/PlatCon.2018.8472752

[51] C. Sharma, R. Sinha, and P. Leitao, "IASelect: Finding best-fit agent practices in industrial CPS using graph databases," IEEE Int. Conf. Ind. Informatics, vol. 2019-July, pp. 1558-1563, 2019. https://doi.org/10.1109/INDIN41052.2019.8972272

[52] A. Tian, J. F. Sequeda, and D. P. Miranker, "QODI: Query as context in automatic data integration," Lect. Notes Comput. Sci. (including Subser. Lect. Notes Artif. Intell. Lect. Notes Bioinformatics), vol. 8218 LNCS, no. PART 1, pp. 624-639, 2013. https://doi.org/10.1007/978-3-642-41335-3_39

[53] U. Khurana and A. Deshpande, "Efficient snapshot retrieval over historical graph data," Proc. - Int. Conf. Data Eng., pp. 997-1008, 2013. https://doi.org/10.1109/ICDE.2013.6544892

[54] D. A. Shibanova and I. V. Stroganov, "Simulation System for Combining Requests of Independent Intelligent Agents to Reduce the Load on the Communication Channel based on a Graph Database using Cars as an Example," Proc. 2020 IEEE Conf. Russ. Young Res. Electr. Electron. Eng. EIConRus 2020, pp. 77-80, 2020. https://doi.org/10.1109/EIConRus49466.2020.9039128

[55] D. W. Wardani and J. Küng, "Property Hypergraphs as an Attributed Predicate RDF," vol. 9415, pp. 329-336, 2015. https://doi.org/10.1007/978-3-319-26148-5 21

[56] S. K. Mukhiya, F. Rabbiab, V. K. I. Punax, A. Rutle, and Y. Lamo, "A graphql approach to healthcare information exchange with hl7 fhir," Procedia Comput. Sci., vol. 160, pp. 338-345, 2019. https://doi.org/10.1016/j.procs.2019.11.082

[57] N. Martínez-Bazan, S. Gómez-Villamor, and F. Escalé-Claveras, "DEX: A high-performance graph database management system," Proc. - Int. Conf. Data Eng., pp. 124-127, 2011. https://doi.org/10.1109/ICDEW.2011.5767616

[58] S. Bordoloi and B. Kalita, "Designing Graph Database Models from Existing Relational Databases," Int. J. Comput. Appl., vol. 74, no. 1, pp. 25-31, 2013. https://doi.org/10.5120/12850-9303

[59] S. Fathimabi, R. B. V. Subramanyam, and D. V. L. N. Somayajulu, "MSP: Multiple Sub-Graph Query Processing 
using Structure-based Graph Partitioning Strategy and Map-Reduce,” J. King Saud Univ. - Comput. Inf. Sci., vol. 31, no. 1, pp. 22-34, 2019. https://doi.org/10.1016/j.jksuci.2016.11.007

[60] A. Vaisman, F. Besteiro, and M. Valverde, "Modelling and Querying Star and Snowflake Warehouses Using Graph Databases," Commun. Comput. Inf. Sci., vol. 1064, pp. 144-152, 2019. https://doi.org/10.1007/978-3-030-302788_18

[61] J. Zou, J. Zhao, B. Lang, and Y. Zhao, "Achieving effective and efficient attributed graph data management using lucene,” ACM Int. Conf. Proceeding Ser., pp. 7-13, 2018. https://doi.org/10.1145/3226116.3226119

[62] A. Llorens-Carrodeguas, C. Cervelló-Pastor, and I. Leyva-Pupo, "A data distribution service in a hierarchical SDN architecture: implementation and evaluation," Proc. - Int. Conf. Comput. Commun. Networks, ICCCN, vol. 2019July, 2019. https://doi.org/10.1109/ICCCN.2019.8847035

[63] J. Martinez-Gil et al., "General model for tracking manufacturing products using graph databases," Data-Driven Process Discovery and Analysis, Springer, pp. 86-100, 2018. https://doi.org/10.1007/978-3-030-46633-6_5

[64] T. Chen, C. Yuan, G. Liu, and R. Dai, "Graph based Platform for Electricity Market Study, Education and Training," IEEE Power Energy Soc. Gen. Meet., vol. 2018-Augus, pp. 1-5, 2018. https://doi.org/10.1109/PESGM.2018.8586243

[65] G. F. Pelap, C. F. Zucker, and F. Gandon, "Semantic models in web based educational system integration," WEBIST 2018 - Proc. 14th Int. Conf. Web Inf. Syst. Technol., pp. 78-89, 2018. https://doi.org/10.5220/0006940000780089

\section{BIOGRAPHY OF AUTHORS}

\section{Adhy Rizaldy}

The Author is a lecturer in Department of Information System, Faculty of Science and Technology, Universitas Islam Negeri Alauddin Makassar. The author graduated from Institut Teknologi Sepuluh Nopember for Sarjana at 2011, and from Dian Nuswantoro University (UDINUS) for Master degree on 2017. Author actively writes from scientific to research papers on various topics i.e. Tex tMining, Machine Learning, etc. Subjects that have been taught include Pemrograman Mobile, Pemrograman Dasar, Pemrograman Visual, Struktur Data, Algoritma dan Pemrograman, Aplikasi Komputer, Pemrograman Berorientasi Objek, dan Sistem Operasi.

\section{Sirli Fahriah}

Sirli Fahriah is a lecturer in Informatics Engineering in Politeknik Negeri Semarang. The co-author completed her S1 and S2 degree at Dian Nuswantoro University (UDINUS). Miss Sirli actively writes from scientific to research papers on various topics i.e. Data Mining, Machine Learning, etc. Subjects that have been taught include Database Administrators, Dasar Komputer, Algoritma dan Pemrograman, Komunikasi Data, Sistem Basis Data, dan Sistem Operasi.

\section{Nahrun Hartono}

Nahrun Hartono is a lecturer in Department of Information System, Faculty of Science and Technology, Universitas Islam Negeri Makassar. Completed his Master at the STMIK AMIKOM in 2016, and graduated for Sarjana from Universitas Satria Makassar. 